\title{
THE BEA SCORE IN CHRONIC HEPATITIS B AND DELTA
}

\section{Tofan-Scutaru Liudmila, Berliba Elina, Peltec Angela, Turcanu Adela, Turcan Svetlana, Rotaru-Cojocari Diana}

\author{
State University of Medicine and Pharmacy "Nicolae Testimiţanu», \\ Chisinau, Republic of Moldova
}

SUMMARY. The aim of the work was to study the BEA score (Baseline Event-anticipation score) and its correlation with biological signs of liver laboratory syndromes in the patients with chronic hepatitis B and Delta.

There were investigated prospectively 58 Caucasian patients with chronic hepatitis B and Delta (CHD), 28 women and 30 men, and 10 Caucasian patients with viral liver cirrhosis Delta (LCD). BEA score was estimated using the online calculator (http://hepatitis-delta.org/physicians-and-scientists/calculators/).

There was estimated the BEA score and the indicators of the biological liver syndromes were studied. The correlation analysis was performed (after Spearman) between the score values of BEA parameters and the biological liver syndromes.

It was established the direct correlation of the BEA score with the values of the levels of serum gamma-glutamyl transferees and with the serum total bilirubin in patients with HCD. In patients with LCD there was determined direct correlation of the BEA score with the total bilirubin and inverse correlation with the serum albumin values.

We recommend modifying the BEA score by adding the albumin and GGT as predictors for developing complications related to liver disease.

KEY WORDS: chronic hepatitis delta, BEA score, liver laboratory syndromes.

Introduction. Hepatitis $D$ is the most severe form of viral hepatitis, but the variables associated with its progression remain poorly defined. Studies have shown that chronic HBV/HDV co-infection leads to more severe hepatic conditions, accelerated progression of fibrosis, and eventually, to higher risk of hepatocellular carcinoma and early decompensation in case of development of hepatic cirrhosis, compared to chronic HBV monoinfection $[1,2,3,5,8,9,10,11]$. There is no efficient approved standard treatment for chronic hepatitis D. None of the actual antiviral agents used for $B$ and $D$ coinfection is capable of curing the disease $[4,6,7]$. Identifying the risk factors that predict the development of infavourable clinical events is considered useful in long term monitorisation of patients with chronic HDV infection, especially for selecting those patients in need for urgent antiviral treatment. The BEA score (baseline-event-anticipation) is a clinically predictive score, which predicts the development of complications related to the hepatic condition - decompensation, hepatocellular carcinoma, liver transplant and/or death (1). This is achieved by anticipating the events and is based on evaluating the values associated with the development of complications related to the pathology. The following indices are assessed for the calculation of BEA score: age, sex, origin, INR (International Normalized Ratio), bilirubin and platelet count (12). The score is allocated according to the reported risk. Three risk groups are defined: BEA-A - minor risk (0-2 points), BEA-B moderate risk (2-4 points), BEA-C - major risk (> 4 points). An easy to apply clinical score, the Baseline-Event-Anticipation- (BEA) Score, can help to identify patients with a more severe course (11).
Objectives. The study of biological hepatic syndromes in patients with chronic viral hepatitis D, assessment of BEA score and its correlation to the indices of hepatic biologic syndromes.

Materials and methods. The clinical material was selected from the data acquired in the Department of Gastroenterology of The Clinical Republican Hospital, Chisinau, Republic of Moldova, in 2015. Inclusion criteria: The patients were included in the test sample according to the following criteria: Caucasian origin, clinical, biological and imagistical diagnosis of chronic hepatitis, presence of serum HBsAg, as well as anti-HDV antibodies and HDV-RNA for more than 6 months. Exclusion criteria: East Mediterranean origin, severe associated pathology (cardiac, renal, endocrine), concomitant HCV or HIV infection, autoimmune hepatitis, association with toxic or alcoholic hepatitis, hepatic cirrhosis, hepatic tumors including hepatocellular carcinoma.

The test sample (TS) included 58 patients: 30 men $(51.8 \%)$ and 28 women (48.2 \%) with chronic viral hepatitis $D$. The mean age was 46.9 years (age between 23 and 73 years), $75 \%$ of women and 76.7 $\%$ of men had an age over 40 years.

The control sample (CS) included 10 patients (6 men and 4 women) with the diagnosis of hepatic cirrhosis of HDV etiology. The mean age was 45.1 years (age between 28 and 55 years) of which 8 patients were more than 40 years old. The severity of cirrhosis was described as follows: 5 patients had Child-Pugh stage A, 2 patients had Child-Pugh stage B, 3 patients had Child-Pugh stage $C$.

The biologic hepatic syndromes were analyzed. The cytolysis syndrome was assessed by determining 
Огляди літератури, оригінальні дослідження, погляд на проблему

the values of Alanine-Aminotransferase (ALT) and Aspartate-Aminotransferase (AST) using the standard tests according to IFCC (International Federation of Clinical Chemistry and Laboratory Medicine). For the assessment of cholestasis syndrome the level of total bilirubin and conjugated bilirubin were determined by diazo method (L. Iendrassik 1936), Alkaline Phosphatase was determined by standard photometric test, Gamma Glutamyl transferaze - using the photometric method of Szasz G. and Perijn J. 1974. The following assessments were made for the hepatoprive syndrome: total proteins (unified Biuret method), serum albumin (colorimetric method with green bromcresol), prothrombin time (PT) (Quick method), converted to International Normalized Ratio (INR) a ccording to a standard formula.

The immune-inflammatory syndrome was assessed using the following data: complete blood count using the hematologic analyzer PCE-210, humoral immunity parameters- the level of seric IgA, IgM, IgG (radial immunodiffusion assay, Mancini 1965), level of circulating immune complexes (precipitation with polyethylene glycol solution Grinevici I.A.

The statistical analysis of data was performed using EXCEL and SPSS and the functions and modules included. The analysis of the correlation between continuous variables was performed using the Pearson correlation coefficients, in case of normal distribution of the variables, and Spearman in case of variables lacking normal distribution or ordinary variables. For establishing the statistical significance of the difference between the test and control samples we have chosen a non parametric procedure of data analysis, the U-Mann-Whitmey test, given the unequal number of subjects in the two samples.
Results. The patients selected had the same origin, Caucasian; the variation in BEA the score was due to the other parameters: sex, age, INR, total bilirubin, platelet count. By evaluating the respective indices in the test sample the results are: $36.2 \%$ were included in BEA-A, low risk of developing complications and $63.8 \%$ in BEA-B, moderate risk of developing complications. In the control sample $20 \%$ were included in BEA-A, $50 \%$ in BEA-B and $30 \%$ in BEA-C, major risk of complications (Fig. 1).

The BEA score in the test sample $(1.9 \pm 0.8)$ was significantly lower $(p=0.005 ; p<0.01)$ than the score in the control sample ( $3.3 \pm 1.4$ ) (Tab. 1).

The citolysis syndrome was well noted in both samples, but the indices in the test sample: ALT (115.5 \pm 24.5 $\mathrm{U} / \mathrm{l})$ and AST $(76.4 \pm 16.4 \mathrm{U} / \mathrm{l})$ were insignificantly higher compared to the data in the control sample: ALT $(54.5 \pm 15.1 \mathrm{U} / \mathrm{l})$ and AST $(53.9 \pm 23 \mathrm{U} / \mathrm{l})$. The assessment of the colestasis syndrome has revealed that te total bilirubin level in the TS $(24.9 \pm 3.17 \mathrm{umol} / \mathrm{l})$ was significantly lower $(p=0.036 ; p<0.05)$ than in the CS $(52 \pm 5.7 \mathrm{umol} / \mathrm{l})$. The GGT levels in the TS $(63.94 \pm 7.1 \mathrm{U} / \mathrm{l})$ were also significantly lower $(p=0.003, p<0.005)$ compared to the $\mathrm{CS}(110.04 \pm 5.2 \mathrm{U} / \mathrm{l})$. The Alkaline Phosphatase levels had no significant variation in the two samples.

The assessment of the immune-inflamatory syndrome has revealed high levels of CIC and IgG in both samples with no significant difference. The evaluation of the indices of the hepatoprive syndrome has revealed significant difference between the two samples. The serum albumin in the TS $(37.98 \pm 4.7 \mathrm{~g} / \mathrm{l})$ has levels that significantly $(p=0.003)$ exceed the levels in the CS $(29.9 \pm 7.6 \mathrm{~g} / \mathrm{l})$. The prothrombin time in the TS is within the normal range $(89 \pm 11.9 \%)$ and significantly exceeds $(p=0.001)$ the lower data in the CS $(63.9 \pm 6.2)$.

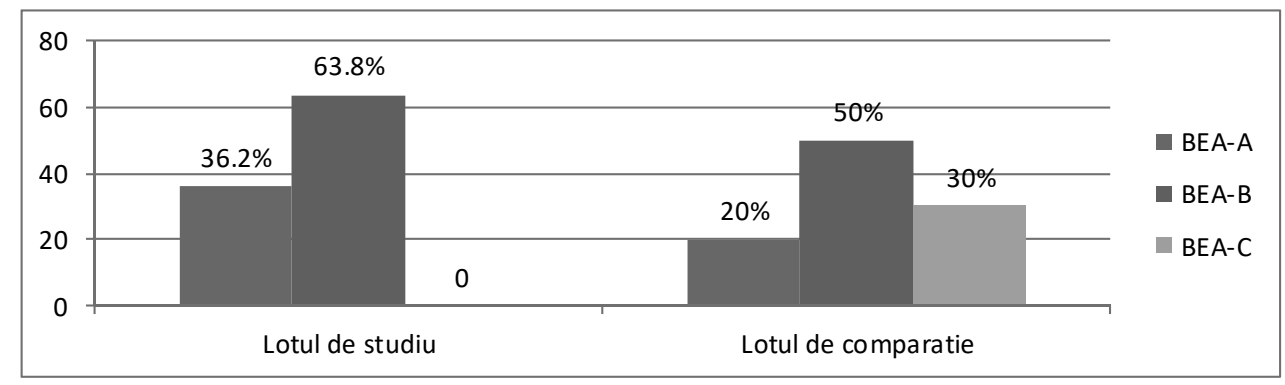

Figure 1. The distribution of the patients in the test sample and control sample compared to the sum of the BEA scores obtained.

Table 1. The number of patients collated with the BEA score

\begin{tabular}{|l|c|c|}
\hline BEA score & Test sample & Control sample \\
\hline 1 & 21 & 1 \\
\hline 2 & 23 & 3 \\
\hline 3 & 12 & 2 \\
\hline 4 & 2 & 3 \\
\hline 5 & 0 & 1 \\
\hline
\end{tabular}


Огляди літератури, оригінальні дослідження, погляд на проблему

In the TS a statistically significant positive, but weak correlation was found of the BEA $(1.91 \pm 0.84)$ score with the GGT serum levels $\left(r^{s}=0.284, p<0.05\right)$; and a strong expected correlation with the total serum bilirubin $\left(r^{s}=0.732, p<0.001\right)$.
In the CS we found a direct correlation of the BEA $(3.30 \pm 1.49)$ score with the total serum bilirubin $\left(r^{s}=0.656, p<0.05\right)$ and a strong negative correlation $\left(r^{s}=-0.653, p<0.05\right)$ with the serum albumin levels $(29.90 \pm 7.59 \mathrm{~g} / \mathrm{l})$ (Tab. 2).

Table 2. Correlation indices of the BEA score with the parameters of the biological hepatic syndromes in the test and control samples

\begin{tabular}{|l|c|c|c|c|}
\hline \multirow{2}{*}{ Parameters } & \multicolumn{2}{|c|}{ BEA score in the test sample } & \multicolumn{2}{c|}{ BEA score in the control sample } \\
\cline { 2 - 5 } & Correlation coefficient $\left(r^{s}\right)$ & Significance level $(p)$ & Correlation coefficient $\left(r^{s}\right)$ & Significance level $(p)$ \\
\hline ALT & 0.003 & 0.979 & -0.355 & 0.314 \\
\hline AST & -0.065 & 0.625 & 0.120 & 0.742 \\
\hline Bilirubin & $0.732^{* * *}$ & 0.001 & $0.656^{* * *}$ & 0.039 \\
\hline GGT & $0.284^{*}$ & 0.031 & -0.031 & 0.931 \\
\hline White blood cell & -0.169 & 0.204 & 0.212 & 0.557 \\
\hline Albumin & 0.044 & 0.746 & $-0.653^{* * *}$ & 0.041 \\
\hline
\end{tabular}

Discussions. In the management of the patients with hepatic illness it is important to evaluate the individual risk of disease progression. This is very difficult in patients with hepatitis $D$ given the insufficient efficacy of the antiviral treatment. The BEA score was the first clinical score to be used in medical practice for the prognosis of the evolution in hapatitis $D$. The score is important for the management of the patients, to decide which patients need urgent antiviral treatment or a careful supervision. The treatment should be preferentially administred to patients higher risk of disease progression and hepatic complications. Therefore, the BEA score can select the patientas at higher risk of developing a hepatic event in a short term. These patients can be offered an urgent treatment. While the patients with a lower risk of hepatic events could expect more efficient new alternatives. The BEA score was found to be easy to apply, and has a high precision in distinguishing the patients at minor, moderate or major risk of developing complications related to liver disease. Its validity was also accepted for patients with cirrhosis [1].

The correlations obtained in our study confirmed that bilirubin, as a well documented parameter of liver function evaluation, is a clinically predictive factor which is valid for the patients with chronic hepatitis $D$ and with cirrhosis of HBV and HDV etiology. There is a high probability that the serum albumin could be used as well for the prognosis of the hepatic complications in patients with hepatic cirrhosis of HBV and HDV etiology, as, according to our results, it has a strong negative correlattion to the BEA score. The direct correlation between the BEA score and the GGT level needs additional studies, given the significant, although weak, correlation revealed in our study. The addition of serum albumin and serum GGT as clinical predictive factors to the BEA score could optimize the assessment of the risk of developing hepatic complications in patients with chronic hepatitis $D$ and with cirrhosis of HBV and HDV etiology. The clinical scores for the assessment of the level of hepatic affectation and for the anticipation of complications risk in patients with liver disease needs sistematic evaluation, especially in hepatitis D.

Conclusions. 1. The BEA score was significantly lower $(p=0.005)$ in the test sample $(1.91 \pm 0.84)$ than in the control sample $(3.30 \pm 1.49)$, which confirms the lower risk of developing hepatic complications in patients with chronic hepatitis $D$ compared to those with hepatic cirrhosis.

2. The bilirubin levels in the test sample $(24.9 \pm 3.17 \mathrm{umol} / \mathrm{l})$ were significantly lower $(p=0.036)$ compared to the control sample $(52 \pm 5.7 \mathrm{umol} / \mathrm{l})$.

3. A direct correlation of BEA score $(1.91 \pm 0.84)$ with total serum bilirubin was found in caucasian patients in the test sample $\left(r^{s}=0.732, p<0.001\right)$. A direct correlation ( $\left.{ }^{\mathrm{s}}=0.656, \quad \mathrm{p}=0.039\right)$ of BEA score $(3.30 \pm 1.49)$ with total serum bilirubin was also found in the control sample.

4. In the patients with chronic hepatitis $B$ and $D$ (test sample) a statistically significant positive weak correlation $\left(r^{s}=0.284, p<0.05\right)$ was found of the BEA $(1.91 \pm 0.84)$ score with the GGT serum levels $(63.94 \pm 7.1 \mathrm{U} / \mathrm{l})$.

5. In the test sample serum albumin levels $(37.98 \pm 4.7 \mathrm{~g} / \mathrm{l})$ were significantly $(p=0.003)$ higher than the levels in the liver cirrhosis (control simple) $(29.9 \pm 7.6 \mathrm{~g} / \mathrm{l})$.

6. A strong negative correlation $\left(r^{s}=-0.653\right.$, $p=0.041$ ) of serum albumin levels with BEA score in patients with hepatic cirrhosis of HBV and HDV etiology was found.

7. The modiffication of the BEA score by adding of serum albumin and serum GGT as clinical predictive factors could optimize the assessment of the risk of developing hepatic complications in relation to liver disease caused by mixed HBV and HDV infection. 
Огляди літератури, оригінальні дослідження, погляд на проблему

BIBLIOGRAPHY

1. Development and evaluation of a baseline-eventanticipation score for hepatitis delta / B. Calle Serrano, A. Grosshennig, M. Homs [et al.] // Journal of Viral Hepatitis. - 2014. - Vol. 21. - P. e154-e163.

2. Molecular interactions between hepatitis $B$ virus and delta virus / Elham Shirvani-Dastgerdi, Frank Tacke // World J. Virol. - 2015. - Vol. 4(2). - P. 36-41.

3. Heidrich B.HBeAg-positive hepatitis delta:virological patterns and clinical long-term outcome / B. Heidrich, B. C. Serrano // Liver Int. - 2012. - Vol. 32. - P. 1415-1425.

4. Hepatitis delta virus / S. A. Hughes, H. Wedemeyer, P. M. Harrison // Lancet. - 2011. - Vol. 378. - P. 73-85.

5. Prevalence and clinical course of hepatitis delta infection in Greece: a 13-year prospective study / E. K. Manesis, G. Vourli, G. Dalekos [et al.] // J. Hepatol. - 2013. - Vol. 59. P. 949-956.

6. Mauss Stefan. Hepatology. Stefan Mauss. - A clinical textbook. 7th Edition, 2016. - 709 p.
7. Price J. An update on hepatitis B, D, and E viruses / J. Price // Top Antivir. Med. - 2014. - Vol. 21. - P. 157-163.

8. High serum levels of HDV RNA are predictors of cirrhosis and liver cancer in patients with chronic hepatitis delta / R. Romeo, B. Foglieni, G. Casazza [et al.] // PLoS One. - 2014. - Vol. 9. - P. e92062.

9. Hepatitis D and hepatocellular carcinoma / Zaigham Abbas, Minaam Abbas, Sarim Abbas, Lubna Shazi // World J. Hepatol. - 2015. - Vol. 7(5). - P. 777-786.

10. Wranke A Aktuelles Management der Hepatitis Delta / A. Wranke, S. Hardtke, H. Wedemeyer // Journal für Gastroenterologische und Hepatologische Erkrankungen. - 2015. - Vol. 13 (4). - P. 11-17.

11. Anti-HDV IgM as a marker of disease activity in hepatitis delta / A. Wranke, B. Heidrich, S. Ernst [et al.] // PLoS One. - 2014. - Vol. 9. - P. e101002.

12. http://hepatitis-delta.org/physicians-and-scientists/ calculators/ - BEA-Score Calculator

\title{
ШКАЛА ВЕА ПРИ ХРОНІЧНОМУ ГЕПАТИТІ В І ДЕЛЬТА ○Тофан-Ссутару Людміла, Берліба Еліна, Пелтес Ангела, Турсану Адела, Турсан Светлана, Ротару-Сойосарі Діана
}

\author{
Державний медичний і фармацевтичнй університет імені Миколи Тестемицану, Кишинів, \\ Республіка Молдова
}

РЕЗЮМЕ. Вивчення у кавказьких пацієнтів з хронічним вірусним гепатитом В і дельта шкали BEA (Baseline Event - anticipation score) і визначення його кореляції з параметрами лабораторних печінкових синдромів. Були проспективно досліджені 58 кавказьких пацієнта з хронічним гепатитом В і дельта (28 жінок і 30 чоловіків) і 10 кавказьких пацієнтів з вірусним цирозом печінки В і дельта. Оцінка за шкалою ВЕА була розрахована 3 використанням онлайн-калькулятора (http://hepatitis - delta.org/physicians - and - scientists/calculators/). Bивчені показники лабораторних синдромів печінки. Проводили кореляційний аналіз між балами оцінки ВЕА і цих біологічних синдромів печінки. Встановлена пряма залежність між балами оцінки ВЕА зі значеннями рівнів сироваткової гама-глутамілтрансферази та із загальним білірубіном сироватки у хворих на хронічний гепатит дельта. Була визначена пряма залежність між балами оцінки BEA із загальним білірубіном і зворотна кореляція зі значеннями альбуміну сироватки у хворих з цирозом печінки В і дельта. Рекомендуємо оптимізацію оцінки ВЕА шляхом додавання альбуміну і гама-глутамілтрансферази в якості провісників розвитку ускладнень, пов'язаних із захворюванням печінки.

КЛЮчОВІ СЛОВА: хронічний гепатит дельта, шкала ВЕА, параметри лабораторних печінкових синдромів. 